\title{
Evaluation of Protein Concentration, Amino Acid Profile and Antinutritional Compounds in Hempseed Meal from Dioecious and Monoecious Varieties
}

\author{
Roberto Russo, Remo Reggiani \\ Istituto di Biologia e Biotecnologia Agraria, CNR, Via Bassini 15, Milano, Italy \\ Email: reggiani@ibba.cnr.it
}

Received 2 October 2014; revised 5 November 2014; accepted 12 December 2014

Copyright (C) 2015 by authors and Scientific Research Publishing Inc.

This work is licensed under the Creative Commons Attribution International License (CC BY). http://creativecommons.org/licenses/by/4.0/

(c) (i) Open Access

\begin{abstract}
Hempseed meal from three dioecious and three monoecious varieties has been evaluated for content and quality of the protein and for the concentration of antinutritional compounds. Hemp seeds were obtained from plants grown in two experimental fields for two consecutive years (2011-2012). For all the varieties, hempseed meal resulted in a rich source of protein $(34 \%$ mean content) with an amino acid profile extremely rich in arginine and slightly poor in lysine. Differences between dioecious and monoecious varieties were observed in the content of antinutritional compounds. They were more concentrated in monoecious varieties in comparison with those dioecious. The concentration of phytic acid in hempseed meal deserves attention in both groups, being 63 and $75.4 \mathrm{~g} \cdot \mathrm{kg}^{-1}$ of dry matter in dioecious and monocieous varieties, respectively. The results show that, besides the recognized value of hemp oil, also the hempseed cake could find application in animal feed as a substitute of other cakes (soybean, rapeseed). From this point of view, the dioecious varieties showing lower contents of antinutritional compounds with respect to the monoecious varieties would be preferred.
\end{abstract}

Keywords

Antinutritional Compounds, Amino acid Profile, Dioecious, Monoecious, Protein

\section{Introduction}

Hemp (Cannabis sativa L.) is an annual herbaceous plant belonging to Cannabinaceae family known to have

How to cite this paper: Russo, R. and Reggiani, R. (2015) Evaluation of Protein Concentration, Amino Acid Profile and Antinutritional Compounds in Hempseed Meal from Dioecious and Monoecious Varieties. American Journal of Plant Sciences, 6, 14-22. http://dx.doi.org/10.4236/ajps.2015.61003 
played a historically important role in food, fiber and medicine production. For centuries, it has been considered as one of the most important agricultural crops by providing necessities such as cordage, cloth, food, lighting oil and medicines. In Europe, it was mainly utilized as a source of fiber and seed. In 1999, the EU produced about $27,000 \mathrm{t}$ of hemp fiber and $6200 \mathrm{t}$ of hemp seed, mostly in France, and $90 \%$ of this was used as animal feed. In particular, the seeds have traditionally been employed as feed for bird and poultry [1]. In other parts of the world, it was primarily used as a source of psychoactive drug [2]. Hemp has the greatest economical potential if grown both for seeds and stems (fibers) as residual agricultural products [3].

Hempseed contains more than $30 \%$ oil of which more than $80 \%$ is polyunsaturated fatty acids [4]. Hempseed oil is especially rich in two essential fatty acids-linoleic acid (18:2, omega-6) and alpha-linolenic acid (18:3, omega-3). They are present in a ratio of about 3:1, considered optimal in healthy human adipose tissue [5], and apparently unique among common plant oils [6]. This preferred omega-6/omega-3 ratio was successfully utilized in animal feed to manipulate the fatty acid pattern in bovine adipose tissue and eggs [7] [8]. There are various benefits attributed to omega- 3 and include anti-cancer, anti-inflammatory and anti-thrombosis properties, stimulation of general metabolism and promotion of burning fat [5] [9].

Hempseed oil is commonly extracted by solvents and, the resulting by-product, is known as hempseed meal (HSM) which has good protein level ranging from 30\% to $40 \%$ in dry matter (DM) of flour depending upon the variety of hemp used [10]. HSM is a rich source of protein and energy and can represent a nutritious feed supplement for livestock or used for production of a high-protein flour.

Identification and characterization of hempseed proteins showed that edestin, rich in valuable amino acids, constituted the main protein component in isolate hempseed protein [11]. Another protein structure, rich in methionine and cystine, was found in hemp seeds and subsequently characterized as an albumin protein family member [12]. Numerous factors are known to influence the nutritional quality of plant proteins, as measured by their amino acid composition and digestibility. The amino acid composition may be affected by genotypic variability or agronomic conditions such as soil fertility and postharvest processing that alters the ratio of seed components (e.g. shelling). The digestibility of proteins may be affected by protein structure, the presence of antinutritional compounds and high temperature processing [13].

HSM contains antinutritional compounds that need to be considered when feeding this product. In hempseed, among a vast number of antinutritional compounds, phytate has raised more attention [14]. Phytic acid (inositol exaphosphate) is the main organic form of phosphorus present in plant seeds. Its presence reduces protein digestibility and increases the excretion of endogenous nitrogen, amino acids and minerals, in particular bivalent cations [15]. Another nutritionally important group of compounds are the condensed tannins. Tannins (flavan-3-ol based biopolymers) are known to negatively affect nitrogenous compounds uptake, absorption of minerals, and reduce weight gain and feed consumption intake in broiler chicks [16]. In the case of sorghum, $1 \%$ of increased tannin content reduced the dietary energy value by $10 \%$ [17]. Being protein precipitants, the tannins form complexes with feed proteins and endogenous enzymes. Hence, the weight of the pancreas increases if the feed contains high levels of tannins [18]. Other deleterious compounds considered by animal nutritionists are the saponins. These substances consist of a sugar moiety usually containing one sugar (glucose, galactose, glucuronic acid, xylose, rhamnose or methylpentose), glycosidically linked to a hydrophobic aglycone (sapogenin) which may be in nature triterpenoid or steroid [19]. Dietary saponins depressed growth, feed consumption and egg production in poultry [20]. These negative effects have been ascribed to several properties of saponins such as reduced feed intake caused by the astringent and irritating taste of saponins, reduction in intestinal motility and reduction in protein digestibility, probably due to the formation of sparingly digestible saponin-protein complexes [19]. Moreover, saponins have pronounced haemolytic properties and are responsible for bloat in ruminats [21]. Trypsin inhibitors are considered one of the most important antinutritional factors and are found in many species of graminaceous, cruciferous and leguminosae. In literature, there are few data about the trypsin inhibitor activities in HSM [12]. Lastly, the metabolism of some substances contained in flour may lead to the release of toxic products (e.g. cyanogenic glycosides to hydrogen cyanide) [22].

In the present study, HSM was evaluated as protein source (content and quality) and for the presence of the main antinutritional compounds (phytic acid, condensed tannins, cyanogenic glycosides, trypsin inhibitors and saponins). Two groups of hemp varieties were used. The first group was consisting of dioecious varieties (Carmagnola, Carmagnola Selezionata [CS], Fibranova) and the second group of monoecious varieties (Fedora 17, Felina 32, Ferimon). The dioecious and monoecious hemp varieties have strong differences in the flowering time and seed filling [23]. The characterization of these biochemical features will help to better understand the nutritional quality of HSM and its use as feed ingredient. 


\section{Materials and Methods}

\subsection{Plant Materials and Field Experiment}

The experimental field trials on hemp were carried out for two consecutive years (2011-2012) in Italy in two different locations of Lombardy region: Treviglio $\left(45^{\circ} 31^{\prime} \mathrm{N}, 9^{\circ} 35^{\prime} \mathrm{E}\right.$; $125 \mathrm{~m}$ AMSL) and Cavriana $\left(45^{\circ} 20^{\prime} \mathrm{N}\right.$, $10^{\circ} 35^{\prime} \mathrm{E} ; 170 \mathrm{AMSL}$ ). The growing degree units were 579 and 645 for the two years (2011 and 2012, respectively) in Treviglio, and 667 and 721 in Cavriana for the same years. The total rainfall during the growth period of the hemp plants was 428 and $482 \mathrm{~mm}$ in the two years in Treviglio, and 498 and 344 for the same period in Cavriana. In both sites, the experimental design included the evaluation of 3 dioecious (Carmagnola, CS and Fibranova) and 3 monoecious varieties (Futura 75, Felina 32 and Ferimon). The experimental design was a randomized complete block with 3 replicate plots $\left(10 \mathrm{~m}^{2} / \mathrm{block}\right)$ of each variety. Hemp plots were harvested at full maturity stage. Seeds were forced-air dried $\left(30^{\circ} \mathrm{C}\right)$ in a ventilated chamber until $8 \%$ seed moisture was reached.

\subsection{Oil Extraction and Protein Assay}

Seeds were ground in a mortar and mixed with hexane $(1: 10, \mathrm{w} / \mathrm{v})$. The solution was vigorously shaken for 30 min. After centrifugation, the upper-liquid was collected and the extraction procedure repeated. The dried flour was used for analyses.

Protein was extracted from defatted flours by Plant Total Protein Extraction Kit (Sigma-Aldrich, Milan, Italy). The kit includes two reagents, a plant specific protease inhibitor cocktail and a chaotropic reagent with increased solubilizing power to extract more hydrophobic proteins. Protein content was determined by Quantum Protein Kit (Euroclone, Milan, Italy) using Bovine Serum Albumin (BSA) as standard.

\subsection{Amino Acid Composition}

In order to obtain the amino acid profile of the protein of the six varieties of hemp, the protein of each variety was extracted from a mixture of flours from the various plots. Fifty $\mu \mathrm{L}$ of protein extract was subjected to acid hydrolysis in $3 \mathrm{M}$ mercaptoethanesulfonic acid containing $2 \mathrm{~g} \cdot \mathrm{kg}^{-1} \mathrm{NaN}_{3}$ at $110^{\circ} \mathrm{C}$ for $16 \mathrm{~h}$. Hydrolysed samples were then diluted ten times with HPLC quality water before amino acid analysis. The amino acid composition was determined by HPLC analysis of the 9-fluorenyl-methoxycarbonyl chloride/1-aminoadamantane (FMOC/ ADAM) derivatives. An aliquot (150 $\mu \mathrm{L})$ of sample was added to $150 \mu \mathrm{L}$ of a $200 \mathrm{mM}$ Borate buffer (pH 10.0). Then, $300 \mu \mathrm{L}$ of FMOC-Cl (in acetonitrile) was added and derivatization occurred. After 5 min, the reaction was stopped by the addition of $300 \mu \mathrm{L}$ of $300 \mathrm{mM}$ ADAM in water-acetonitrile $(1: 1, \mathrm{v} / \mathrm{v})$ and the reaction lasted for 1 min to block the excess of FMOC through the formation of FMOC-ADAM complex. Then, the sample was filtered and analyzed by HPLC. The separation of FMOC/ADAM derivatives was performed at a flow rate of $0.9 \mathrm{~mL} \cdot \mathrm{min}^{-1}$ on a $150 \times 4.6 \mathrm{~mm}$ Phenomenex Kinetex C18 $2.6 \mu$ reverse phase column. Two mobile phases were used: a) $50 \mathrm{mM} \mathrm{Na}$-acetate ( $\mathrm{pH} 4.2)$; b) acetonitrile. Phase B was maintained at $28 \%$ (v/v) for 3 min, increased linearly to $45 \%(\mathrm{v} / \mathrm{v})$ over $24 \mathrm{~min}$, increased linearly to $100 \%(\mathrm{v} / \mathrm{v})$ over $5 \mathrm{~min}$, remained to $100 \%$ for 5 $\mathrm{min}$ and then returned to $28 \%(\mathrm{v} / \mathrm{v})$ in 2 min to regenerate the system. Fluorescence labelled amino acids were monitored using a Jasco fluorescence detector (model FP-920) at an excitation wavelength of $263 \mathrm{~nm}$ and emission wavelength of $313 \mathrm{~nm}$.

\subsection{Analysis of Antinutritional Compounds}

Phytic acid, condensed tannins, cyanogenic glycosides and trypsin inhibitors were extracted and assayed according to Russo and Reggiani [24].

Saponins were extracted overnight from defatted flour with absolute methanol (1:20, w/v). The samples were centrifuged for $15 \mathrm{~min}$ at 15,000 rpm and the methanol extract evaporated to dryness. Then the samples were resuspended in water: n-butanol (1:2, v/v). After $1 \mathrm{~h}$ of agitation, the samples were centrifuged and the higher alcoholic layer recovered. Saponin content was estimated according to Goel et al. [25] using Quillaja saponin (Sigma-Aldrich, Milan, Italy) as a reference standard.

\subsection{Statistical Analyses}

All analyses were carried out in triplicate. Analysis of Variance (ANOVA) was applied to establish significant 
differences $(\mathrm{P} \leq 0.01)$ between hemp varieties in the levels of protein and antinutritional compounds using SPSS version 16.0 software. Mean separation was performed using Duncan's test and referring to $\mathrm{P} \leq 0.05$ probability level. Pearson's correlations between antinutritional compounds were also calculated.

\section{Results and Discussion}

\subsection{Hempseed Meal Protein Content}

Figure 1 shows the protein content in six hemp varieties in the two years of cultivation (2011 and 2012) and in the two experimental fields (Treviglio and Cavriana). The protein content in HSM was, on average, $340 \mathrm{~g} \cdot \mathrm{kg}^{-1}$ dry matter (DM). Substantial differences are evident between years of cultivation. In 2012, protein concentration was higher respect to first year for all hemp varieties and in the two experimental fields. This was evidenced also by ANOVA analysis that showed highly significant difference for year of cultivation (Table 1). In 2012, the temperatures recorded during the seed filling were higher in comparison with 2011 (resulting in > growing degree units in both sites), while rainfall resulted more abundant in the first year in Cavriana. As described in literature, during seed formation hemp prefers high temperatures $\left(27^{\circ} \mathrm{C}\right)$ and mild climate [26]. Moreover, high temperatures during seed filling intensify the protein synthesis with an increased protein content in meal due to a better translocation of mineral salts (nitrogen and sulphur) into xylematic tubes [27]. Instead, no difference was observed between dioecious and monoecious hemp groups in protein concentration (Table 2).

Table 1. F values from Analysis of Variance (ANOVA) for biochemical compound contents in six varieties of hemp.

\begin{tabular}{|c|c|c|c|c|c|c|c|}
\hline Source of variance & d.f. $^{\text {a }}$ & Protein & Phytic acid & Condensed tannins & Cyanogenic glycosides & Trypsin inhibitors & Saponins \\
\hline Variety (V) & 5 & $12.37^{* *}$ & $57.02^{* *}$ & $1130.35^{* *}$ & $169.80^{* *}$ & $445.84^{* *}$ & $202.13^{* *}$ \\
\hline Field (F) & 1 & $6.60^{*}$ & 2.94 & $10.18^{* *}$ & $18.73^{* *}$ & 0.48 & 0.01 \\
\hline Year (Y) & 1 & $269.41^{* *}$ & $83.31^{* *}$ & $118.88^{* *}$ & $140.50^{* *}$ & $4.47^{*}$ & $22.07^{* *}$ \\
\hline $\mathrm{VxF}$ & 5 & 0.80 & $5.52^{* *}$ & 0.79 & $7.83^{* *}$ & 2.30 & 1.51 \\
\hline $\mathrm{VxY}$ & 5 & $6.02^{* *}$ & $5.08^{* *}$ & $14.98^{* *}$ & $5.48^{* *}$ & $5.08^{* *}$ & $2.55^{*}$ \\
\hline FxY & 1 & 1.38 & $8.85^{* *}$ & $23.68^{* *}$ & 2.87 & 0.07 & 0.11 \\
\hline VxFxY & 5 & $4.89^{* *}$ & $5.12^{* *}$ & 0.12 & 1.78 & $3.55^{* *}$ & 1.44 \\
\hline
\end{tabular}

${ }^{\mathrm{a}}$ Degrees of freedom; ${ }^{*}$ Significant at $\mathrm{P} \leq 0.05 ;{ }^{* *}$ Significant at $\mathrm{P} \leq 0.01$.

Table 2. Protein and antinutritional compounds in three dioecious and three monoecious hemp varieties.

\begin{tabular}{ccccccc}
\hline Variety & Protein $^{1}$ & Phytic acid $^{1}$ & Condensed tannins $^{1}$ & Cyanogenic glycosides $^{1}$ & Trypsin inhibitors $^{2}$ & Saponins $^{1}$ \\
\hline Carmagnola & $337(\mathrm{~cd})$ & $63.6(\mathrm{~cd})$ & $2.14(\mathrm{~d})$ & $0.09(\mathrm{~d})$ & $22.6(\mathrm{c})$ & $0.47(\mathrm{~d})$ \\
CS & $348(\mathrm{ab})$ & $64.8(\mathrm{c})$ & $2.49(\mathrm{c})$ & $0.08(\mathrm{~d})$ & $21.7(\mathrm{~d})$ & $0.53(\mathrm{c})$ \\
Fibranova & $351(\mathrm{a})$ & $61.5(\mathrm{~d})$ & $2.21(\mathrm{~d})$ & $0.05(\mathrm{e})$ & $10.8(\mathrm{e})$ & $0.49(\mathrm{~d})$ \\
Futura 75 & $342(\mathrm{bc})$ & $75.7(\mathrm{ab})$ & $4.56(\mathrm{a})$ & $0.12(\mathrm{c})$ & $27.3(\mathrm{a})$ & $0.65(\mathrm{~b})$ \\
Felina 32 & $351(\mathrm{a})$ & $76.7(\mathrm{a})$ & $4.42(\mathrm{~b})$ & $0.17(\mathrm{a})$ & $26.2(\mathrm{~b})$ & $0.68(\mathrm{a})$ \\
Ferimon & $331(\mathrm{~d})$ & $73.9(\mathrm{~b})$ & $4.40(\mathrm{~b})$ & $0.15(\mathrm{~b})$ & $27.7(\mathrm{a})$ & $0.70(\mathrm{a})$ \\
Mean \pm SE & $343 \pm 3.3$ & $69.4 \pm 2.8$ & $3.50 \pm 0.48$ & $0.11 \pm 0.02$ & $22.7 \pm 2.6$ & $0.59 \pm 0.04$ \\
P group & 0.40 & $<0.01$ & $<0.01$ & $<0.01$ & $<0.01$ & $<0.01$ \\
\hline
\end{tabular}

${ }^{1}$ Data expressed as $\mathrm{g} \cdot \mathrm{kg}^{-1}$; ${ }^{2}$ Data expressed as unit $\cdot \mathrm{mg}^{-1}$; Means with different letters in parentheses within the same row differ significantly by Duncan's range test $(\mathrm{P} \leq 0.05)$. 


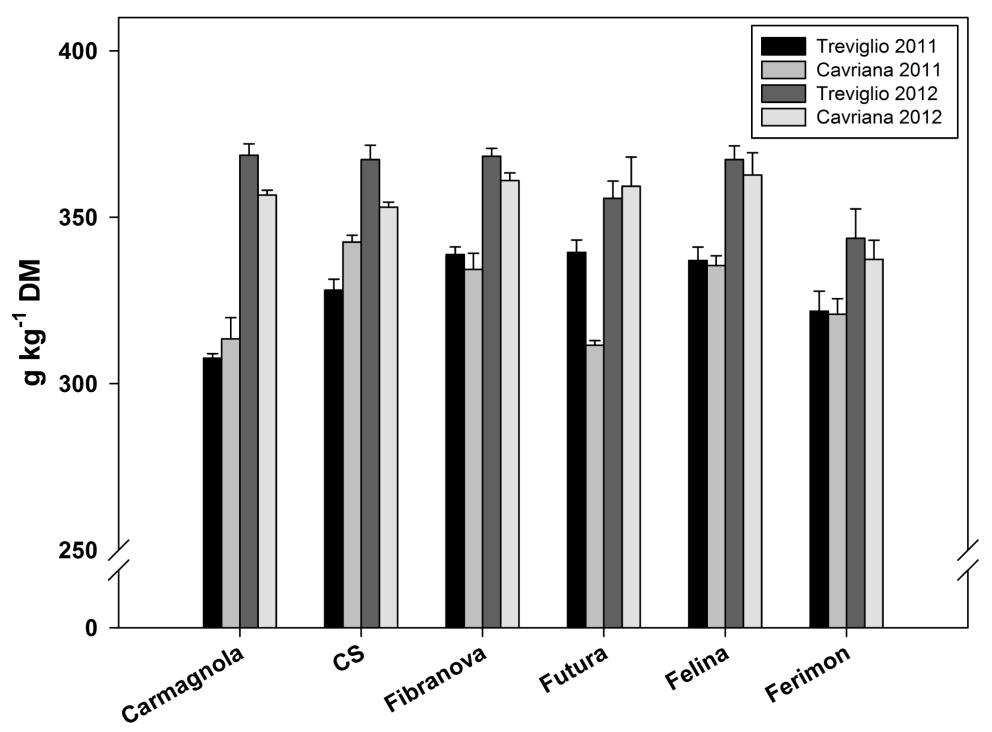

Figure 1. Protein content in flours of six varieties of hemp in the two experimental fields (Treviglio and Cavriana) and two years of cultivation (2011 and 2012).

\subsection{Amino Acid Profile in Hemp Protein}

The Table 3 shows the amino acid (AA) concentration in hydrolyzed protein of six varieties of hemp. The nutritional value of protein is determined by the profile of essential AAs (threonine, methionine, valine, phenylanine, isoleucine, leucine, tryptophan, histidine and lysine). Among AAs, glutamate and arginine were predominant in

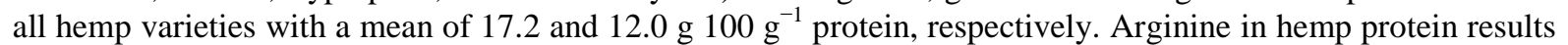
higher respect to soybean and almost double than in rapeseed protein [28] [29]. This datum could be very interesting for feed industries, since young mammals have a high dietary requirement for arginine due to its role as a nitrogen carrier in tissue proteins and its key role in gastrointestinal growth and development. Some researchers consider arginine as a key essential AA for maximal growth of young pigs [30], especially for piglet plasma concentrations decline throughout a sow's lactation [31].

Among the essential AAs, threonine content was higher in the group of monoecious varieties (Futura 75, Felina 32, Ferimon) than in dioecious varieties (Carmagnola, CS, Fibranova). Plant storage protein is often poor in

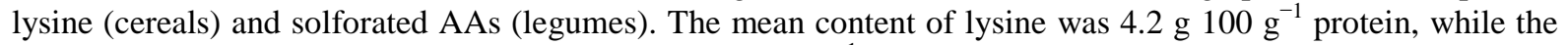

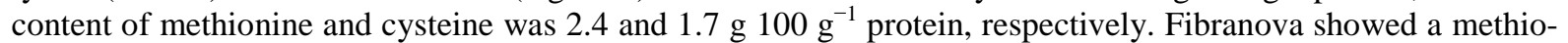
nine content (2.8 g $100 \mathrm{~g}^{-1}$ protein) significantly above the mean. Lysine and methionine have been identified frequently as first limiting essential AAs in feedstuffs of growing cattle and lactating cows. Hemp protein results deficient in lysine respect to soybean and rapeseed proteins [28] [29]. Instead, methionine content is higher than in soybean and rapeseed proteins [28] [29]. Feedstuffs rich in methionine are very important for feed industries that often use methionine additive analogues to ensure animal requirements. In fact, methionine is clearly recognized as first limiting AA in poultry, high-yielding cows and third limiting AA in pigs [32].

As described by House et al. [33], the PDCAAS (protein digestibility corrected amino acid score) value for hemp protein sources is about 0.5 - 0.6 and is positioned in the same range as the major pulse protein sources (e.g. beans, lentils), and above cereal grain products, such as whole wheat. The PDCAAS value for hemp protein will continue to remain in this range due to the limitation in lysine content. Future breeding efforts to increase lysine content in hemp may be guaranteed if the value of the protein component for animal consumption will lead to the development of a market for this crop. Therefore, HSM could partly replace soybean meal, in European feed industries, to reduce the expensive import costs of soy from South America. Hempseed derivedproducts are already used as feed material for all species [32]. In Mustafa et al. [34], each sheep was feed up to $200 \mathrm{~g} \cdot \mathrm{kg}^{-1}$ of HSM and concluded that HSM is an excellent source of RUP (rumen undegraded protein), with high post-ruminal availability, and may replace canola and soybean meal with no detrimental effects on nutrient utilization by sheep. Data from feeding trials indicate that HSM could be used up to $20 \%$ in laying hens diets, although Gakhar et al. [35] reported a reduction of body weight of hen after a 4 weeks diet. 
Table 3. Amino acid content (g $100 \mathrm{~g}^{-1}$ protein) in hydrolyzed proteins of six varieties of hemp.

\begin{tabular}{ccccccccccccccccccc}
\hline Variety & Arg & Ser & Asx & Glx & Thr & Gly & Ala & Tyr & Pro & Met & Val & Phe & Ile & Leu & Cys & Trp & His & Lys \\
\hline Carmagnola & 12.6 & 5.6 & 11.3 & 17.5 & 2.6 & 4.6 & 5.3 & 3.9 & 4.7 & 2.5 & 5.0 & 4.9 & 3.9 & 6.5 & 1.4 & 0.7 & 2.8 & 4.3 \\
CS & 11.6 & 5.4 & 11.3 & 17.2 & 2.6 & 4.8 & 5.1 & 3.4 & 4.8 & 2.3 & 5.5 & 4.7 & 4.2 & 6.9 & 1.8 & 0.8 & 2.8 & 4.0 \\
Fibranova & 11.5 & 4.9 & 10.3 & 17.3 & 3.1 & 5.0 & 5.2 & 4.0 & 5.1 & 2.8 & 5.0 & 4.6 & 3.9 & 7.1 & 1.9 & 0.9 & 3.1 & 4.4 \\
Futura 75 & 11.9 & 5.4 & 11.1 & 17.7 & 3.6 & 5.0 & 5.3 & 2.9 & 4.9 & 2.1 & 5.1 & 4.8 & 4.0 & 7.1 & 1.4 & 0.8 & 2.8 & 4.0 \\
Felina 32 & 12.5 & 5.3 & 11.0 & 16.7 & 3.7 & 5.0 & 5.1 & 3.0 & 4.1 & 2.4 & 5.5 & 4.6 & 4.4 & 7.1 & 1.8 & 0.9 & 2.9 & 4.0 \\
Ferimon & 11.6 & 4.9 & 10.5 & 17.0 & 3.9 & 4.9 & 5.0 & 3.8 & 4.5 & 2.1 & 5.7 & 4.6 & 4.1 & 6.9 & 1.9 & 0.8 & 3.2 & 4.6 \\
Mean & 12.0 & 5.3 & 10.9 & 17.2 & 3.3 & 4.9 & 5.2 & 3.5 & 4.7 & 2.4 & 5.3 & 4.7 & 4.1 & 6.9 & 1.7 & 0.8 & 2.9 & 4.2 \\
SE & 0.3 & 0.2 & 0.2 & 0.2 & 0.3 & 0.1 & 0.1 & 0.3 & 0.2 & 0.2 & 0.2 & 0.1 & 0.1 & 0.1 & 0.1 & $<0.1$ & 0.1 & 0.2 \\
\hline
\end{tabular}

\subsection{Antinutritional Compounds in Hempseed Meal}

In Table 1 it shows ANOVA for phytic acid, condensed tannins, cyanogenic glycosides, trypsin inhibitors and saponins for six varieties of hemp. ANOVA showed that is present a great significant variability for varieties, year of cultivation and their interaction for all the antinutritionals. Instead, variability attributable to experimental fields was significant only for condensed tannins and cyanogenic glycosides. In Table 2 it shows the levels of antinutritional compounds for the three dioecious varieties and the three monocieous varieties. For each group is shown the significance of variability between groups (P). As can be seen, phytic acid was lower in dioecious varieties than in monocieous varieties. This huge difference between the two groups was put in evidence by the $P$ value and the Duncan's test. These elevated contents of phytic acid observed in defatted hemp flour are definitely higher than soybean (2\%) or rapeseed (2.2\%) [29] [36]. The main effect of phytic acid is the binding of important mineral nutrients (iron, zinc, calcium, phosphorus) which is a major concern when HSM is fed to monogastric animals lacking of the phytase enzyme. As a consequence of this, it is advisable to mix HSM with other plant flours exhibiting lower levels of phytic acid (cereals) for its use in monogastric animal feed formulations.

In Table 2 it shows the content of condensed tannins. The monocieous and dioecious groups of plants showed great significant differences between them evidenced by the $\mathrm{P}$ value. The monocieous varieties showed a mean content of condensed tannins (4.46 g $\left.\mathrm{kg}^{-1} \mathrm{DM}\right)$ about double respect to dioecious varieties $\left(2.28 \mathrm{~g} \cdot \mathrm{kg}^{-1} \mathrm{DM}\right)$. Despite the total amount of condensed tannins in HSM resulted higher respect to soybean $\left(0.1 \mathrm{~g} \cdot \mathrm{kg}^{-1}\right)$ [37], it can be considered relatively low if compared with other feed sources like forage [38] and, therefore, a negligible nutritional interference can be expected [39]. Moreover, the tannin level necessary for rejection by grazing animals is about $20 \mathrm{~g} \cdot \mathrm{kg}^{-1} \mathrm{DM}$ [40]. Since Colombini et al. [41] found that low levels of dietary tannins were related to increased yields of fat-corrected milk and protein (possibly due to lower protein degradation in the rumen and lower $\mathrm{N}$ excretion for ruminants), feeding of varieties with the lowest content of condensed tannins (dioecious) would be desirable.

As can be seen, the mean content of cyanogenic glycosides was low even if different between dioecious and monocioeus varieties (Table 2). At levels above $100 \mathrm{ppm}$, the cyanogenic glycosides are dangerous for animal and human health [42]. However, having to dilute HSM with other flours to reduce the content of protein and other antinutritionals, the cyanogenic glycosides content falls below the threshold of $100 \mathrm{ppm}$.

The range of variation for trypsin inhibitor activities in hemp varieties was quite high (Table 2). Trypsin inhibitors are responsible for reduced digestibility of seed proteins, and, for this reason, constitute the main antinutritional factors of plant seed [43]. In Table 2, the activities varied from 10.8 to $27.7 \mathrm{unit}^{\mathrm{mg}}{ }^{-1}$ of defatted flour. However the levels of trypsin inhibitor activities result lower in comparison with those observed in some cereals and soybean [44] [45]. Among hemp varieties, fibranova exhibited the lowest trypsin inhibitor activity (letter "e" by Duncan's range test). Generally plant grains require heat processing to reduce trypsin inhibitors before their use as food or animal feed [44]. However, the excessive heat may decrease protein solubility and amino acid availability. Therefore, flours low in trypsin inhibitor activity could be interesting for feed industries to avoid expensive heat treatments and reduced nutritional quality of feed. The content of saponins showed significant difference among hemp varieties (Table 2). The dioecious group showed a mean content of saponins $\left(0.50 \mathrm{~g} \cdot \mathrm{kg}^{-1}\right)$ lower than that observed in monocioeus varieties $\left(0.68 \mathrm{~g} \cdot \mathrm{kg}^{-1}\right)$. These levels of saponins are lower than that observed in flax and soybean [24] [45].

In Table 4 it shows the correlation matrix calculated for the different antinutritional compounds. The Pearson 
Table 4. Pearson correlation coefficient (r) among antinutritional compounds in six varieties of hemp.

\begin{tabular}{|c|c|c|c|c|c|}
\hline Compounds & Phytic acid & Condensed tannins & Cyanogenic glycosides & Trypsin inhibitors & Saponins \\
\hline Phytic acid & 1 & & & & \\
\hline Condensed tannins & $0.670^{* *}$ & 1 & & & \\
\hline Cyanogenic glycosides & $0.442^{* *}$ & $0.791^{* *}$ & 1 & & \\
\hline Trypsin inhibitors & $0.624^{* *}$ & $0.719^{* *}$ & $0.660^{* *}$ & 1 & \\
\hline Saponins & $0.653^{* *}$ & $0.933^{* *}$ & $0.796^{* *}$ & $0.680^{* *}$ & 1 \\
\hline
\end{tabular}

${ }^{* *}$ Correlation is significant at the 0.01 level.

correlation coefficients are given as a measure of linearity between two class of compounds. From Table 4 it is clear that all the antinutritional compounds considered in the six varieties of hemp are positively correlated. Probably, the biosynthetic pathways of these compounds in hemp are expressed simultaneously during the development of the seed.

\section{Conclusions}

Feed industries need new rich-protein fodder for animal, to increase meat, milk and egg productions. The remaining hemp meal after extraction of oil (which has its own commercial value), could be a new rich protein source available for use as animal feed. HSM shows a good protein content (34\%), an interesting AA profile with elevated levels of arginine (but slightly poor in lysine) and a discrete digestibility of protein. In ruminants, heat treatment of hemp was shown to partially increase protein digestibility although such treatment leads to an increase of costs [46]. Such costs for HSM need to be comparable to other protein feeds to become a viable alternative on commercial farms [46].

The evaluation of antinutritional compounds in HSM varieties, put in evidence the extremely high levels of phytic acid. From this point of view, HSM from dioecious varieties is better than that from monoecious varieties. As mentioned above, the restricted limit of $20 \%$ of HSM in animal diet allows lowering the concentration of antinutritionals and in particular of phytic acid. However, it is important to monitor phytate content in monogastric animal, since exposure of animals to high level of phytate over the long term could cause important nutritionally deficiencies, especially for iron and zinc [47]. To increase the use of HSM in feed would be desirable breeding for low content of phytate. Otherwise, a research has to be undertaken to identify mutants with lowphytic acid occurred in soybean [48].

\section{Acknowledgements}

The authors thank Regione Lombardia for financial support through project "VeLiCa” (no. 14840/RCC) and "FilAgro" (No. 18093/RCC).

\section{References}

[1] Karus, M., Kaup, M. and Lohmeyer, D. (2000) Study on Markets and Prices for Natural Fibres (Germany and EU). Proceedings of the 3rd International symposium-Bioresource Hemp \& Other fibre Crops, Wolfsburg, Germany.

[2] Callaway, J.C. (2008) A More Reliable Evaluation of Hemp THC Levels Is Necessary and Possible. Journal of Industrial Hemp, 13, 117-144. http://dx.doi.org/10.1080/15377880802391142

[3] Johnson, P. (1999) Industrial Hemp: A Critical Review of Claimed Potentials for Cannabis sativa. Tappi Journal, 82, 113-123.

[4] Callaway, J.C. (2004) Hempseed as a Nutritional Resource: An Overview. Euphytica, 140, 65-72. http://dx.doi.org/10.1007/s10681-004-4811-6

[5] Simopoulos, A.P. (2006) Evolutionary Aspects of Diet, the Omega-6/Omega-3 Ratio and Genetic Variation: Nutritional Implications for Chronic Diseases. Biomedicine \& Pharmacotherapy, 60, 502-507.

[6] Matthäus, B. and Brühl, L. (2008) Virgin Hemp Seed Oil: An Interesting Niche Product. European Journal of Lipid Science and Technology, 110, 655-661. http://dx.doi.org/10.1002/ejlt.200700311

[7] Gibb, D.J., Shah, M.A., Mir, P.S. and McAllister, T.A. (2005) Effect of Full-Fat Hemp Seed on Performance and Tis- 
sue Fatty Acids of Feedlot Cattle. Canadian Journal of Animal Science, 85, 223-230. http://dx.doi.org/10.4141/A04-078

[8] Silversides, F.G. and Lefrancois, M.R. (2005) The Effect of Feeding Hemp Seed Meal to Laying Hens. British Poultry Science, 46, 231-235. http://dx.doi.org/10.1080/0071660500066183

[9] Erasmus, U. (1999) Fats That Heal, Fats That Kill. Alive Books, Burnaby.

[10] Eriksson, M. (2007) Hemp Seed Cake as a Protein Feed for Growing Cattle. MSc Thesis, Student Report 128, Swedish University of Agricultural Sciences, Department of Animal Environment and Health, Skara. http://ex-epsilon.slu.se:8080/archive/00001725/01/Absolut_sista_versionen_av_exjobbet,_pdf.pdf

[11] Wang, X.S., Tang, C.H., Yang, X.Q. and Gao, W.R. (2008) Characterization, Amino Acid Composition and in Vitro Digestibility of Hemp (Cannabis sativa L.) Proteins. Food Chemistry, 107, 11-18. http://dx.doi.org/10.1016/j.foodchem.2007.06.064

[12] Odani, S. and Odani, S. (1998) Isolation and Primary Structure of a Methionine- and Cystine-Rich Seed Protein of Cannabis sativa. Bioscience Biotechnology and Biochemistry, 62, 650-654. http://dx.doi.org/10.1271/bbb.62.650

[13] Sarwar, G. (1997) The Protein Digestibility-Corrected Amino Acid Score Method Overestimates Quality of Proteins Containing Antinutritional Factors and of Poorly Digestible Proteins Supplemented with Limiting Amino Acids in Rats. Journal of Nutrition, 127, 758-764. http://jn.nutrition.org/content/127/5/758.full.pdf

[14] Russo, R. and Reggiani, R. (2013) Variability of Antinutritional Compounds in Hempseed Meal of Italian and French Varieties. Plant, 1, 25-29. http://dx.doi.org/10.11648/j.plant.20130102.13

[15] Cowieson, A.J., Acamovic, T. and Bedford, M.R. (2004) The Effects of Phytase and Phytic Acid on the Loss of Endogenous Amino Acids and Minerals from Chickens. British Poultry Science, 45, 101-108. http://dx.doi.org/10.1080/00071660410001668923

[16] Hassank, I.A.G., Elzubeir, E.A. and El Tinay, A.H. (2003) Growth and Apparent Absorption of Minerals in Broiler Chicks Fed Diets with Low or High Tannin Contents. Tropical Animal Health and Production, 35, 189-196. http://dx.doi.org/10.1023/A:1022833820757

[17] Larbier, M. and Leclercq, B. (1994) Nutrition and Feeding of Poultry. Nottingham University Press, Sutton Bonington Campus, Loughborough.

[18] Sharif, M., Idrees, N.A., Tauqir, M.A., Shahzad, M.F., Khalid, M., Nisa, M., Sarwar, M. and Khan, M.L. (2012) Effect of Water Treatment of Sorghum on the Performance of Broiler Chicks. South African Journal of Animal Science, 42, 189-194. http://dx.doi.org/10.4314/sajas.v42i2.12

[19] Francis, G., Kerem, Z., Makkar, H. and Becker, K. (2002) The Biological Action of Saponins in Animal Systems: A Review. British Journal of Nutrition, 88, 587-605. http://dx.doi.org/10.1079/BJN2002725

[20] Jenkins, K.J. and Atwal, A.S. (1994) Effects of Dietary Saponins on Fecal Bile Acids and Neutral Sterols, and Availability of Vitamins A and E in the Chick. Journal of Nutritional Biochemistry, 5, 134-138. http://dx.doi.org/10.1016/0955-2863(94)90084-1

[21] Cheeke, P.R. (1996) Biological Effects of Feed and Forage Saponins and Their Impact on Animal Production. In: Waller, G.R. and Yamasaki, Y., Eds., Saponins Used in Food and Agriculture, Plenum Press, New York, 377-386. http://dx.doi.org/10.1007/978-1-4613-0413-5 32

[22] Newkirk, R. (2009) Flax Feed Industry Guide. Flax Canada 2015, Winnipeg. http://cigi.ca/wp-content/uploads/2011/12/2009_Flax-Feed-Industry-Guide.pdf

[23] Amaducci, S., Colauzzi, M., Zatta, A. and Venturi, G. (2008) Flowering Dynamics in Monoecious and Dioecious Hemp Genotypes. Journal of Industrial Hemp, 13, 5-19. http://dx.doi.org/10.1080/15377880801898691

[24] Russo, R. and Reggiani, R. (2013) Variability of Antinutritional Compounds in Flaxseed Flours. International Journal of Plant Biology, 4, 11-13. http://dx.doi.org/10.4081/pb.2013.e3

[25] Goel, N., Sirohi, S.K. and Dwivedi, J. (2012) Estimation of Total Saponins and Evaluate Their Effect on in Vivo Methanogenesis and Rumen Fermentation Pattern in Wheat Straw Based Diet. Journal of Advanced Veterinary Research, 2, 120-126. http://www.advetresearch.com/index.php/avr/article/view/50/50

[26] Suriyong, S., Vearasilp, S., Krittigamas, N., Pinmanee, S. and Punyalue, A. (2012) Effect of Seed Maturity on Seed Physiological Quality, Oil Content and Fatty Acid Composition of Hemp Seed. Chiang Mai University Journal of Natural Science Special Issue on Agricultural and Natural Resources, 11, 351-358. http://cmuj.cmu.ac.th/sites/default/files/pdf/NaturalSciences/Volume\%2011\%2C\%20Number\%201\%2C\%20Special\% 20Issue\%20on\%20agricultural\%20natural\%20resources/048\%20Journal\%202012-2.pdf

[27] Sainio, P.P., Jauhiainen, L., Hakala, K. and Ojanen, H. (2009) Climate Changes and Prolongation of Growing Season: Changes in Regional Potential for Field Crop Production in Finland. Agricultural and Food Science, 18, 171-190. http://www.mtt.fi/afs/pdf/mtt-afs-v18n3-4p171.pdf 
[28] Zubr, J. (2003) Dietary Fatty Acids and Amino Acids of Camelina sativa Seed. Nutrition and Food Science, 26, 451462. http://dx.doi.org/10.1111/j.1745-4557.2003.tb00260.x

[29] Colombini, S., Broderick, G.A., Galasso, I., Martinelli, T., Rapetti, L., Russo, R. and Reggiani, R. (2014) Evaluation of Camelina sativa (L.) Meal as an Alternative Protein Source in Ruminant Rations. Journal of the Science of Food and Agriculture, 94, 736-743. http://dx.doi.org/10.1002/jsfa.6408

[30] Wu, G., Bazer, F.W., Davis, T.A., Jaeger, L.A., Johnson, G.A., Kim, S.W., Knabe, D.A., Meininger, C.J., Spencer, T.E. and Yin, Y.L. (2007) Important Roles for the Arginine Family of Amino Acids in Swine Nutrition and Production. Livestock Science, 112, 8-22. http://dx.doi.org/10.1016/j.livsci.2007.07.003

[31] Wu, G., Knabe, D.A. and Kim, S.W. (2004) Arginine Nutrition in Neonatal Pigs. The Journal of Nutrition, 134, 27832390. http://jn.nutrition.org/content/134/10/2783S.full.pdf

[32] European Food Safety Authority (2013) Scientific Opinion on the Safety and Efficacy of L-Methionine Produced by Escherichia coli (KCCM 1125P) and Escherichia coli (KCCM 11340P) for All Animal Species. EFSA Panel on Additives and Products or Substances used in Animal Feed (FEEDAP). EFSA Journal, 11, 3428-3443. http://dx.doi.org/10.2903/j.efsa.2013.3428

[33] House, J.D., Neufeld, J. and Leson, G. (2010) Evaluating the Quality of Protein from Hemp Seed (Cannabis sativa L.) Products through the Use of the Protein Digestibility Corrected Amino Acid Score. Journal of Agricultural and Food Chemistry, 58, 11801-11807. http://dx.doi.org/10.1021/jf102636b

[34] Mustafà, A.F., McKinnon, J.J. and Christensen, D.A, (1999) The Nutritive Value of Hemp Meal for Ruminants. Canadian Journal of Animal Science, 79, 91-95. http://dx.doi.org/10.4141/A98-031

[35] Gakhar, N., Goldberg, E., Jing, M., Gibson, R. and House, J.D. (2012) Effect of Feeding Hemp Seed and Hemp Seed Oil on Laying Hen Performance and Egg Yolk Fatty Acid Content: Evidence of Their Safety and Efficacy for Laying Hen Diets. Poultry Science, 91, 701-711. http://dx.doi.org/10.3382/ps.2011-01825

[36] Kwanyuen, P. and Burton, J.W.A. (2005) Simple and Rapid Procedure for Phytate Determination in Soybeans and Soy Products. Journal of the American Oil Chemists' Society, 82, 81-85. http://dx.doi.org/10.1007/s11746-005-1046-9

[37] Matthäus, B. and Zubr, J. (2000) Variability of Specific Components in Camelina sativa Oilseed Cakes. Industrial Crops and Products, 12, 9-18. http://dx.doi.org/10.1016/S0926-6690(99)00040-0

[38] Piluzza, G., Sulas, L. and Bullitta, S. (2013) Tannins in Forage Plants and Their Role in Animal Husbandry and Environmental Sustainability: A Review. Grass and Forage Science, 69, 32-48. http://dx.doi.org/10.1111/gfs.12053

[39] Singleton, V.L. (1981) Naturally Occurring Food Toxicants: Phenolic Substances of Plant Origin Common in Foods. Advances in Food Research, 27, 149-242. http://dx.doi.org/10.1016/S0065-2628(08)60299-2

[40] Kumar, R. and Singh, M. (1984) Tannins: Their Adverse Role in Ruminant Nutrition. Journal of Agricultural and Food Chemistry, 32, 447-453. http://dx.doi.org/10.1021/jf00123a006

[41] Colombini, S., Colombari, G., Crovetto, G.M., Galassi, G. and Rapetti, L. (2009) Tannin Treated Lucerne Silage in Dairy Cow Feeding. Italian Journal of Animal Science, 8, 289-291. http://dx.doi.org/10.4081/ijas.2009.s2.289

[42] Ernesto, M., Cardoso, P., Nicala, D., Mirione, E., Massaza, F. and Cliff, J. (2002) Persistent Konzo and Cyanide Toxicity from Cassava in Northern Mozambique. Acta Tropica, 82, 357-362. http://dx.doi.org/10.1116/S0001-706X(02)00042-6

[43] Peric, V., Srebric, M. and Mladenovic-Drinic, S. (2013) Trypsin Inhibitors in Soybean. Soybean: A Dawn to the Legume World: The Future of Soybean Research Is Already Here. Journal of the International Legume Society, 1, $23-24$.

[44] Sosulki, F.W., Minja, L.A. and Christensen, D.A. (1988) Trypsin Inhibitors and Nutritive Value in Cereals. Plant Foods and Human Nutrition, 38, 23-34. http://dx.doi.org/10.1007/BF01092307

[45] Tsukamoto, C., Shimada, S., Igita, K., Kudou, S., Kokubun, M., Okubo, K. and Kitamura, K. (1995) Factor Affecting Isoflavone Content in Soybean Seeds: Changes in Isoflavones, Saponins, and Composition of Fatty Acids at Different Temperatures during Seed Development. Journal of Agricultural and Food Chemistry, 43, 1184-1192. http://dx.doi.org/10.1021/jf00053a012

[46] Karlsson, L. (2010) Hempseed Cake as a Protein Feed for Ruminants. Ph.D. Dissertation, Swedish University of Agricultural Sciences, Umea. http://pub.epsilon.slu.se/2394/1/Karlsson_L_101103.pdf

[47] Reddy, M.B. and Cook, J.D. (1991) Assessment of Dietary Determinants of Nonheme-Iron Absorption in Humans and Rats. The American Journal of Clinical Nutrition, 54, 723-728. http://ajcn.nutrition.org/content/54/4/723.full.pdf

[48] Wilcox, J.R., Premachandra, G.S., Young, K.A. and Raboy, V. (2000) Isolation of High Seed Inorganic P, Low Phytate Soybean Mutants. Crop Science, 40, 1601-1605. http://dx.doi.org/10.2135/cropsci2000.4061601x 
Scientific Research Publishing (SCIRP) is one of the largest Open Access journal publishers. It is currently publishing more than 200 open access, online, peer-reviewed journals covering a wide range of academic disciplines. SCIRP serves the worldwide academic communities and contributes to the progress and application of science with its publication.

Other selected journals from SCIRP are listed as below. Submit your manuscript to us via either submit@scirp.org or Online Submission Portal.
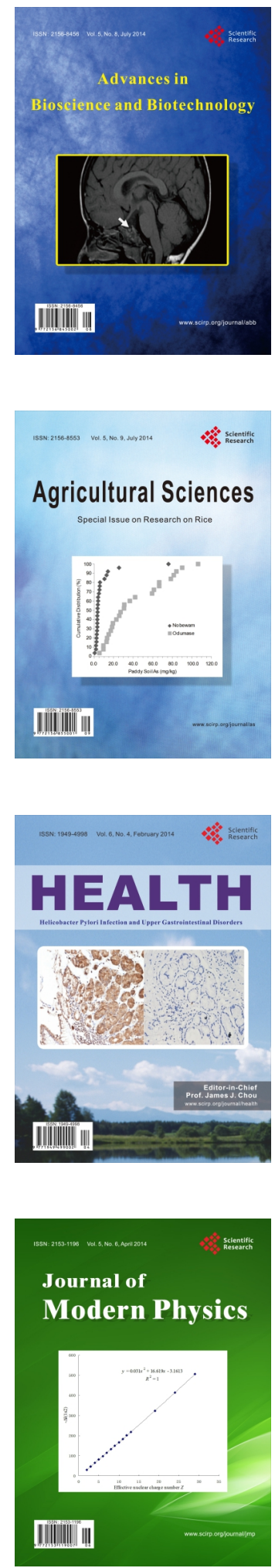
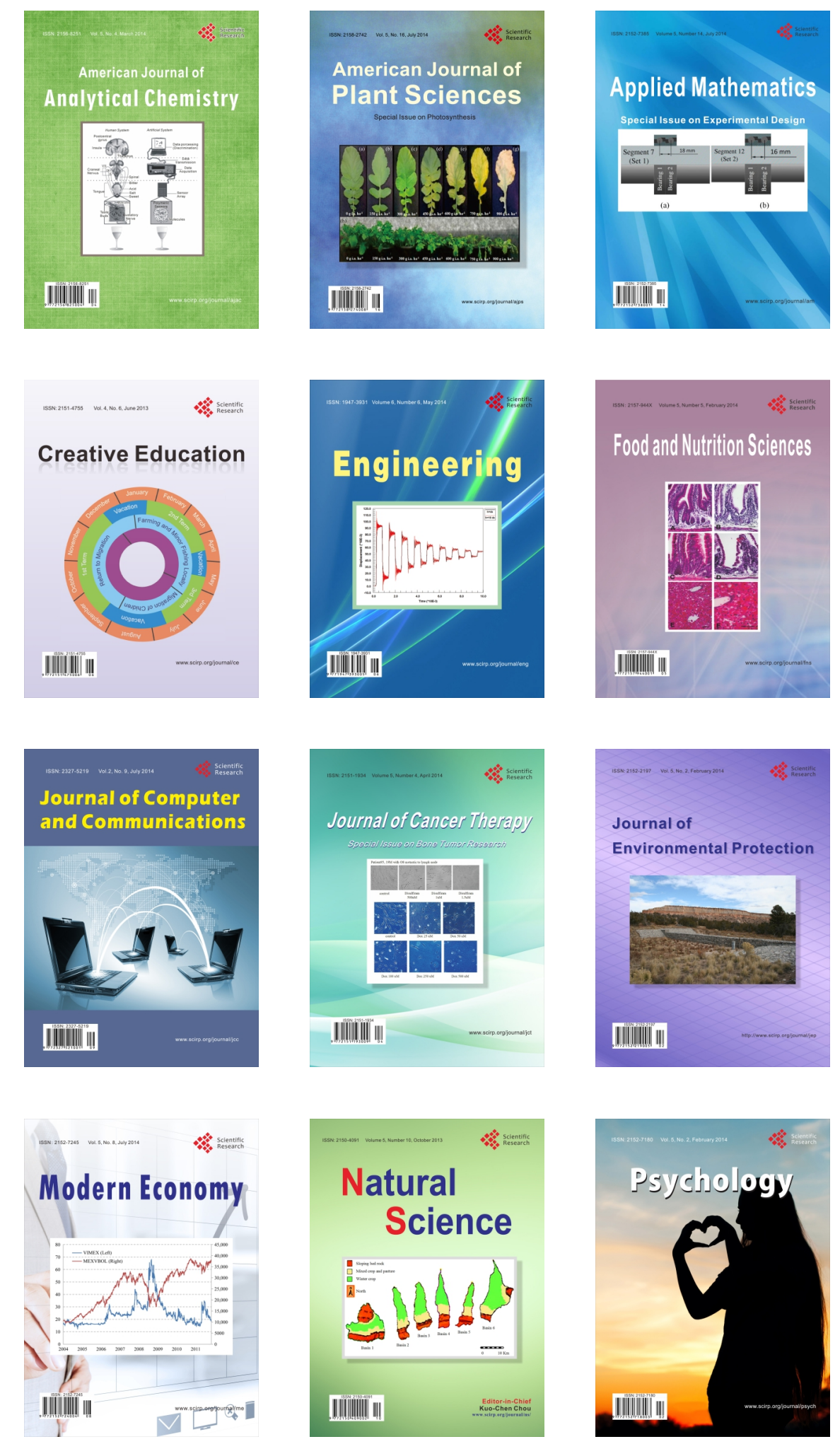